\title{
Argentine Concordat as an International Agreement Regulating the Law of Patronage
}

\author{
Marta Zuzanna Osuchowska \\ iD https://orcid.org/0000-0001-9950-7458 \\ University Cardinal Stefan Wyszyński in Warsaw (UKSW) \\ Faculty of Law and Administration \\ e-mail: m.osuchowska@uksw.edu.pl
}

\section{Abstract}

In the history of relations between the Argentinean government and the Holy See, two ideas are permanently intertwined: signing the Concordat and defending national patronage. The changes that occurred in the $1960 \mathrm{~s}$ indicated that exercising the right of patronage, based on the principles outlined in the Constitution, was impossible, and the peaceful establishment of the principles of bilateral relations could only be indicated through an international agreement. The Concordat signed by Argentina in 1966 removed the national patronage, but the changes to the content of the Constitution were introduced only in 1994. The aim of the study is to show the concordat agreement concluded in 1966 by Argentina with the Holy See as an example of an international agreement. The main focus is the presentation of concordat standards for the institution of patronage. Due to the subject and purpose of the study, the work uses methods typical of social sciences in the legal science discipline. The dogmatic-legal method is the basis for consideration of the Concordat as a source of Argentine law, and as an auxiliary method, the historical-legal method was used to show the historical background of the presented issue.

Keywords: patronage, Argentina, Holy See, Concordat, Constitution 


\section{Introduction}

The conclusion of the agreement between the Holy See and the Argentine Republic had been discussed since the beginning of the new state. A number of political problems, however, did not allow the state to shape a stable central government that could carry out the negotiation process and end it successfully. On the other hand, differences in the views on the patronage law that always prevented the regulation of mutual relations on the diplomatic line were no less critical. Albeit the situation changed over the years, it did not correspond to the normative one. The signing of the Concordat was obvious to both the Holy See and each successive Argentine government. Both parties, however, sought to preserve their privileges, or at least to rationally justify changes in these privileges. In this area a well-established doctrine already existed, and the introduction of revolutionary changes to the highest in the hierarchy of sources of the law of legal acts would make it necessary to search for new solutions.

Since the final political formation of Argentina in 1860 and the adoption of the Constitution throughout the country, the most debatable norms of this law in the field of legal-religious relations included the one that allowed Congress to evaluate canonical documents in terms of their effectiveness on the territory of Argentina. The immediate effect of the so-received right was the possibility of interfering with the episcopate by refusing to recognise the bills of appointment of individual bishops. Article 86 para. 9 of the Constitution was an obstacle to establishing a concordat (Casiello 141). The Holy See could not agree to enter its area of internal law. The principle that was not subject to any discussion was the autonomy to which the Second Vatican Council referred. The changes that took place in the 1960 in the relations between the state and the Church clearly indicated that the exercise of the right of patronage, under the principles set out in the Constitution, was impossible, and the peaceful determination of the principles of bilateral relations could only take place through an international agreement (de Lafuente, Patronato... 104; Furlong 74).

The current state of research makes it possible to approach the subject of the Concordat as a historical document, especially the history of the Church. There is no thorough analysis of the topic in terms of legal research, including the historical-legal method. An analysis of this issue in this perspective makes it possible to understand the impact of the Concordat on current legal regulations in the area of ecclesiastical law, not only within the framework of relations between the state and the Catholic Church, but also other religious entities. Due to the method of its approach, the issue is important for current decisions in the area of institutional relations of ecclesiastical law. The layout of the article is consistent with the temporal approach to the issue of the Argentine Concordat. Therefore, in order to understand the difficulties in negotiating this agreement, it is first necessary to define the nature of the relationship between Argentina and the Holy See, as was presented 
at the beginning of the article. The establishment of bilateral relations and the organisation of religious assistance in the Argentine Armed Forces present the beginnings of cooperation between the two entities. In the following parts of the study, there are direct references to the document itself, together with a presentation of the legal consequences of abolishing the right of patronage in the legal system. Thanks to this way of presenting the subject, the reader can learn about the overall approach to the subject of the study in a systematic way.

\section{Methodology}

The issue of Concordat as an international agreement is discussed from the point of view of legal science discipline. The basic method to explain the legal norms of Concordat as a source of Argentine law is the dogmatic-legal method. Due to the historical background of the issue of patronage, whose origins date back to the colonial period, the historical-legal method was also applied. Thanks to this, information on the development of the institution of patronage and changes in its use on the territory of Argentina was presented comprehensively.

\section{Literature overview}

The current state of research on the issue of Concordat in the area of international law, and not the history of the Catholic Church in Argentina, has not yet been presented in a comprehensive way in the literature on the subject. These issues are addressed within the framework of the Argentine doctrine in the areas of theological and historical sciences, for example, in work C. Bruno, M. Zavala Ortiz, L. García De Loydi, P.J. Frías. It is all the more important to stress the lack of a legal view of the institution of patronage in Argentina as one of the examples of how it operates within the framework of legal-confessional relations. The lack of literature in this area is mainly due to the still underdeveloped branch of ecclesiastical law in Latin American countries. So far, among the few doctrines of ecclesiastical law in Argentina, J.G. Navarro Floria, A. Levaggi, N. Padilla have dealt with the Concordat. In addition, a one-sided view of the institution of patronage and Concordat, including a lack of objectivity in the assessment of actions taken in relations between the state and the churches, is evident in the older literature available, e.g. C. Bruno. The lack of appropriate studies by European specialists in the field of ecclesiastical law is also problematic. The issue of a detailed analysis of the institution of patronage in a concordat in a specifically designated country has not fallen within the scope of interest of European researchers. It is incidentally found in studies for comparative law research. 


\section{Relations of the state with the Holy See before the Concordat}

In the history of the relations between the Argentine government and the Holy See, two ideas were permanently intertwined: the signing of the Concordat and the defence of the exercise of national patronage. From 1810, the only way to harmonise the political vision of the state with the canonical doctrine was the Concordat, which is why both sides sought to sign it. However, before this could happen, it was necessary to restore the broken diplomatic relations. The content of the Concordat was still a secondary matter. ${ }^{1}$

The issue of the Concordat appeared in the history of Argentina many times. One of the most important documents in this regard was Memorial Ajustado prepared by Pedro José Agrelo. It was a collection of official documents and expertises, prepared in response to the appointment of Mariano Medrano bishop of Aulón in partibus infidelium in accordance with the brief Pope Pius VIII of 7 October, 1829 and his confirmation as vicar of the second apostle of 10 March, 1830. In addition, Agrelo joined the appointment documents from 2 June, 1832, Medrano by Pope Gregory XVI. for the diocesan bishop of Buenos Aires and Mariano José de Escalada for the new bishop of Aulón. The author of Memorial Ajustado described the Concordat as a means to agree on common positions of the parties. His idea was shared by most canonists and lawyers whose opinions were attached to Memorial Ajustado. The document "Proposiciones que contienen las bases y principios del procedimiento del Gobierno" also presents the matter of the Concordat and the period of lack of relations with the Holy See. At the same time, it should be emphasised that the initiative to start talks on this matter was left to the Pope and not to the government (Levaggi, Historia... 55-8). ${ }^{2}$

In connection with the political clashes between the supporters of federalism and Unitarianism and the lack of real central power, in particular after the collapse of the Constitutional Congress in 1829, the provinces regained a number of their sovereign powers. This is important in this matter, because at that time the local governments in San Juan and Corrientes were taking action to sign a contract with the Pope to regulate their relations with the church authorities, omitting Buenos Aires.

Since the first attempts to gain independence, successive governments in power in the Río de la Plata failed to reach an agreement with the Holy See.

1 The period of Argentina's lack of communication with the Holy See covers the years 18101858 , vid. A. Tonda, La Iglesia argentina incomunicada con Roma (1810-1858). Problemas, conflictos, soluciones. Santa Fe: Castellví, 1965.

2 Opinion 14th and the last one; opinions of: Gregorio Tagle, Buenaventura Hidalgo, Vicente López y Planes, José María Terrero, Baldomero García y Tomás Manuel de Anchorena. 
The exception was the agreement signed in 1834 between the Province of San Juan and the Apostolic Vicar, Justo Santa María de Oro. In accordance with the provisions of this agreement, the "Ineffabili" bull of Pope Gregory XVI of 19 September, 1834, the episcopal diocese of San Juan de Cuyo as the independent unit of the Church was adopted. The province governor has been granted the patronage right (de Lafuente, Patronato... 112-20). The apostolic Vicar of Cuyo, Justo Santa María de Oro, was appointed on 26 October, 1833, under an agreement creating a new diocese. The mentioned bulla was the only document in the history of Argentina, which granted the secular government the right to present a person for the post of a bishop (Antecedentes 333-40; Verdaguer 104; de Lafuente, Patronato... 28-31, 119-31; Oviedo Cavada 243-55; Zuretti 246; Bruno, Historia... 217-22). At the same time, the Constitution of the province of Corrientes from 1824 gave the executive power the right to depict people for all places and ecclesiastical beneficiaries, on the basis of a concordat. ${ }^{3}$ The second provincial Constitution of the time, which provided for signing the Concordat, was the provisional statute of the Jujuy province of 1835 (Estatuto Provisorio de Jujuy). According to this document, it was the Governor's duty to exercise patronage over the provinces' goods and religious figures until the national government concludes an agreement with the Holy See (Levaggi, Intento... 211-31; San Martino de Dromi 971). ${ }^{4}$

Until the Constituent Congress was convened in 1852, no action was taken to sign the Concordat by the central authorities. This issue, however, was addressed by the doctrine, which affected the content of constitutional projects prepared by Juan Bautista Alberdi and Pedro De Angelis. The second document contained several provisions, including keeping respectful relations with the Holy See, but without diminishing the rights of secular authority in the field of patronage; ${ }^{5}$ permission of Congress to take actions related to the adoption of a concordat throughout the country; ${ }^{6}$ signing concordats by the President (San Martino de Dromi 2461, 2467, 2474). ${ }^{7}$ Alberdi's project had no direct reference to agreements with the Holy See, but in reference to the patronage, it supported the right to present candidates for church posts and consent to receive papal

3 Art. 6: "La provisión y presentación a todas las piezas, y beneficios Ecleciásticos, baxos las bases del concordato que deberá promover, concluir con la Autoridad Ecleciástica del Obispado, y con consulta y aprobación del Congreso Permanente."

4 Sección 5a art. 37, inc. 17: "(...) ejercer el patronato de los benefcios y personas eclesiásticas de la provincia hasta que el gobierno nacional celebre un concordato con la Silla Apostólica."

5 Art. 10: "(...)las relaciones con la Santa Sede serán las más cordiales y respetuosas, sin mengua de las prerrogativas nacionales."

6 Art. 47 inc. 8: „(...) dar instrucciones para celebrar concordatos con la Silla Apostólica, ratifcarlos y arreglar el ejercicio del patronato en toda la República."

7 Art. 84 inc. 16, "(...) celebrar concordatos con la Silla Apostólica, en los términos prescriptos en el artículo 47". 
documents. Despite such a design of the project, Congress added a wording authorising it to approve and reject international agreements and determine how to exercise patronage throughout the Confederation. ${ }^{8}$

After the end of the period of state formation and the adoption of the 1853 federal constitution, further attempts to reach an agreement with the Holy See failed due to disagreement over the issue of patronage and the acceptance by Argentina of the guarantee of freedom of worship in Art. 14 of the Constitution. In connection with the contemporary understanding of the idea of the Concordat (the socalled era of classical concordats), nineteenth-century treaties were conditioned by the announcement of the state's confessionality, which in the case of Argentina was impossible due to the then binding Constitution (Bruno, Base... 255-70).

In the first half of the 2oth century, no projects were directly undertaken to sign the Concordat. A confidential memorandum presented in 1926 by Miguel de Andrea to Cardinal Gasparri, expressed the will of the state to conclude an agreement with the Holy See but had no legal consequences. An intensification of activities took place only after the end of the second Presidency of Perón, during which the relations between the state and the Church reached the maximum level of tension, as in the years 1954-1955. After the overthrow of Perón, the period of rapprochement began in these relations, culminating in the signing of the agreement in 1966. The presence in Rome as Ambassador Manuel Río in 1956-1958 was a decisive factor in improving mutual relations. He was personally responsible for establishing a dialogue with the Holy See. ${ }^{9}$

Argentina remained in economic and political chaos for the next decades. Lack of permanent political strength and frequent changes of government deepened the financial problems of the state. This influenced the change in the way of thinking and acting for the entire Argentine society, including the Church, which was reformed in the early 1960 s with Vatican II. However, separation of secular and spiritual power was impossible, as the government retained the right of patronage, and the lack of separation of these two entities threatened the freedom of the Argentine Church, subordinating it to the politics of the secular government. The Second Vatican Council saw the problems of countries in which patronage was in force and made this issue the subject of the debate. In order

8 Art. 64, inc. 19, "(...) aprobar o desechar los tratados concluidos con las demás naciones, y los concordatos con la Silla Apostólica; y arreglar el ejercicio del patronato en toda la Confederación", y por el artículo 83, inciso 14, el presidente "concluye y firma (...) concordatos (....)."

9 More on this aspects: L. García De Loydi, La Iglesia frente al peronismo. Bosquejo histórico, Buenos Aires: CIC, 1956; D. Corallini, D. Rodríguez Lamas, Encuentros y desencuentros de un pueblo. La Iglesia durante los gobiernos justicialistas, Buenos Aires: Guadalupe, 1988; L. Caimari, Perón y la Iglesia Católica. Religión, Estado y sociedad en la Argentina (1943-1955), Buenos Aires: Ariel, 1995; R. Bosca, La Iglesia nacional peronista. Factor religioso y poder político, Buenos Aires: Sudamericana, 1997; S. Bianchi, Catolicismo y peronismo. Religión y política en la Argentina. 19431955, Buenos Aires: Prometeo-IEHS, 2001. 
to protect its freedom and to ensure the good of the faithful, the Church recommended the abolition of the rights and privileges of the civil authorities to appoint, present or designate candidates for the office of the bishop (Levaggi, Historia... 93-4).

\section{Agreement on religious assistance in the Argentine Armed Forces}

The agreement regarding religious assistance in the Armed Forces, concluded on 28 June 1957 by the military government, should be regarded as the first Argentine Concordat in the broad sense of the term (N. Padilla, J.G. Navarro Floria 15-20). On the basis of this act, the Vicariate of Castrense was established in Argentina, which in fact existed already from 1810. This agreement was subsequently updated by an exchange of notes on 21 April, 1992, in order to adapt it to the provisions of the Apostolic Constitution Spirituali Militum Curae and the conversion of the Vicariate into a bishopric - Military Ordinariate (Ordinariato Castrense) (Navarro Floria, Precisiones jurídicas..., Navarro Floria, La singular... 252).

The interim government of Pedro Eugenio Aramburu Silveti in 1957 came to an agreement with the Holy See on the organisation of military pastoral work in the Argentine army. It was the first bilateral legal act concluded between the Holy See and Argentina, and therefore immediately preceded the agreement of 1966 (Hanna; Decretum... 866-68). On 28 June, 1957, undersecretary of state for Asuntos Eclesiásticos Extraordinarios, Doménico Tardini, and Argentina's ambassador, Manuel Río, signed an agreement on "atención religiosa de las Fuerzas Armadas". The implementation of the goals contained in this agreement, i.e. spiritual care over land, sea and air forces, was to take place within the Vicariato Castrense. The Pope, with the consent of the President as the head of the Armed Forces, was to appoint the bishop of Vicariato Castrense, which took place in 1957. The President's consent was only required to appoint a military vicar. Each of the three chief chaplains for individual types of Armed Forces was to be appointed by the clergyman himself. He was also entitled to appoint a provocateur. In such a procedure, however, patronage was not violated, because the need for the Senate to list three candidates for office and submit it to the President in order to appoint one of them, concerned only the bishops of the Ordinary. Due to the fact that Vicariate Castrense did not have the status of a diocese, it was possible to apply a different solution to the vicar. ${ }^{10}$

Spiritual assistance in the Armed Forces has existed since the beginning of the establishment of the state, but the lack of regular government has caused

10 Acuerdo entre la Santa Sede y la República Argentina. 
difficulties in the implementation of such activities. Difficulties intensified as a result of Perón's conflict with the Church. The revolutionary government set up a research commission that stated that it was necessary to have an ad hoc organisation with its own hierarchy, a special ecclesiastical jurisdiction ratione personae. Chancellor Alfonso de Laferrère and under-secretary of cult Roberto H. Lanusse were determined to promote this initiative. The proposal was sent to Rome, and the ambassador discussed the matter with the secretary of the Congregation for Extraordinary Church Matters, Antonio Samoré, assisted by Monsignor Agostino Casaroli and with whom the representative of the Secretariat of State, Domenico Tardini and his deputy, Angelo Dell'Acqua, cooperated. After receiving the credentials, Tardini and Ambassador Río signed the agreement. For the first time, the bilateral relations between the Holy See and the Argentine Republic were formally regulated. The agreement was immediately ratified by the Pope and by the President. ${ }^{11}$ The exchange of notes took place in the Argentine Ministry of Foreign Affairs on 8 July between the Apostolic Nuncio Mario Zanin and Minister Laferrère. After the entry into force of the agreement, Pope Pius XII appointed Fermín E. Lafitte as the first vicar of Ordinariate (Río 59-74).

The document contains sixteen articles. The Holy See established a vicariate in Argentina, consisting of a military vicar who is a bishop appointed by the Holy See in agreement with the President, and three major chaplains, respectively for each type of armed forces, also after the candidates have been accepted by the relevant ministry. The jurisdiction of the Vicariate includes all military staff in active service, their wives, children, other relatives and domestic personnel living together in military and cadet facilities, laypersons and clerics living in institutions or places reserved for military personnel. Chaplains have parish competences and in the case of general mobilisation, priests perform military service in the form of religious help. Other clergy and religious are assigned to auxiliary services of chaplains or medical organisations. The ordinaries, parish priests, church rectors, religious superiors and personnel necessary in diocesan curia and seminaries are exempt from military service.

For the first time in the history of Argentina, the agreement between the Holy See and the national government determined that both forces would appoint the bishop by mutual agreement, even though he was only a vicar of the Ordinariate. In practice, this was used by modus vivendi, but it was a novelty that a legal title was established, although to a limited extent (de Lafuente, La situación concordataria... 362). However, the question of patronage remained unresolved, in particular the constitutional norms regarding its implementation.

11 Decree-Law No. 7623/1957. 


\section{Conclusion of the Concordat in 1966}

The international agreement with the Holy See, which comprehensively regulated the relations between the state and the Church, was a concordat signed in Buenos Aires on 10 October, 1966, which ended Argentine's claims regarding patronage and ordered the legal situation of the Catholic Church in the country (de Lafuente, El acuerdo... 115; Frías, El acuerdo... 227). ${ }^{12}$ At that time, the Constitution of 1953 was in force, and although it was changed several times, in 1860, 1866, 1898 , and 1957, the institution of patronage remained in an unchanged form from the very beginning, as did Art. 2, which in the government's opinion justified the exercise of this right (Bermúdez 74). In the opinion of the deputies of subsequent constitutional congresses, patronage was one of the attributes of a sovereign state inherited from the Spanish Crown (Legón 292; Salinas Arenda 52). From the point of view of the Catholic side, on the basis of patronage, the Church was limited in the implementation of its own autonomy. It was also pointed out that thanks to their patronage, liberal governments, presidents and ministers, were able to interfere in the rights of the Church (Estrada 22 i n.). For most representatives of the constitutional doctrine, the patronage was, however, an inherent right of sovereignty, as long as there was support for Catholic worship provided for in Art. 2 (González Calderón 79). Even people who did not agree with this solution understood that the resulting situation could be changed only through constitutional reform. At the same time, they were aware of the fact that a debate could be a source of divisions in society and, consequently, bring unpredictable results. Attempts to consolidate the patronage in the second half of the $19^{\text {th }}$ century, and in particular to obtain its formal acceptance from the Church, by signing a bilateral concordat agreement. They were rejected by successive governments who were afraid that in this way Church authorities would strengthen their position (Legón 303). In this situation, the Holy See and the Republic of Argentina worked out a modus vivendi for more than a hundred years, according to which no episcopal appointments were made or dioceses were created without prior presentation provided for in the Constitution (de Lafuente, La situación concordataria... 13; Frías, El acuerdo... 9; Casaroli 363).

On 1 May, 1958, President Arturo Frondizi replaced Aramburu in this position. Santiago de Estrada was delegated to Rome. The importance of Frondizi's government and its strong international position made it possible to implement a plan aimed at establishing a new order of relations with the Church authorities. Frodizi's visit to the Vatican in 1960 was positively received, thanks to which he managed to gain the trust of Pope John XXIII. The instructions issued by the President

12 More on this aspects: M.A. Zavala Ortiz, Negociaciones para el acuerdo entre la Santa Sede y la República Argentina, Buenos Aires: Guadalupe, 1966; J.L. Kaufmann, La presentación de obispos en el patronato regio y su aplicación en la legislación argentina, Buenos Aires: Dunken, 1996. 
since his office, as well as his attention devoted to matters concerning the Church, determined the commencement of the proclamation aimed at signing the Concordat. From the very beginning, it was decided to leave contact with the episcopate to get his opinion on the most important problems that concern him (Centeno 10, $36,45)$.

Frondizi's presidency ended suddenly on 29 March, 1962, as a result of the overthrow of the Armed Forces. During the rule of José María Guido, the circumstances were not conducive to progress in negotiations with Rome, although religious matters have not ceased to be taken into account. Positive actions include the lack of restrictions on the adoption of papal bulls and the abolition of the obligation of bishops to submit an oath of obedience to secular law. To resolve the relationship between the Church and the state, it was necessary to restore constitutional power, which took place on 12 October, 1963, after Arturo Umberto Illia took power.

After a period of political instability and the radical rule of Arturo Illia in 1963, negotiations were resumed and concrete steps were taken to eliminate the patronage of the Argentine legal system. The first official contacts that led to the signing of the Concordat were initiated in October 1965, when on the occasion of the stay of Pope Paul VI at the United Nations headquarters in New York, the Minister of Foreign Affairs, Miguel Ángel Zavala Ortiz, handed the Pope a memorial in which the President of Argentina suggested his readiness to grant the Church all rights and privileges corresponding to its mission and proposed concluding a contract. This document was welcomed by the Holy See.

A series of steps undertaken in 1965 led to the conclusion of the Concordat. The project was prepared and presented by the Apostolic Nuncio Humberto Mozzoni. The text of the document was sent in March of the same year to the Holy See which proposed some modifications. Mutual exchange and determination of the content of the act was completed with the adoption of the fifth project by initialling the text on 6 June, 1966. Negotiations were conducted for eight years, above all with the Argentine episcopate. When the details were finally determined, the date of the signing of the treaty by the Apostolic Nuncio - Humberto Mozzoni and the Minister of Foreign Affairs - Zavala Ortiz was agreed. In the process, however, it was necessary to circumvent the provisions of the Basic Law, in which there were still norms concerning patronage and the principle of unilaterally regulating the relations with the Church by the state. For this purpose, a broad interpretation of the verb arreglar was made, which was included in the constitutional provision specifying the exercise of patronage. It was assumed that if this norm allowed unilateral actions by the state, in the field of discretion, a mutual regulation of matters was also possible.

If the modification of the modus vivendi in Argentina's patronage was the work of successive governments as a part of an uninterrupted policy, especially the Frondizi Presidency, the negotiations on the agreement were the outcome of the work done 
by the government led by Arturo Illia, with direct involvement of the Minister of Foreign Affairs and Cult, Miguel Angel Zavali Ortiz. The day before signing the agreed document, which was to take place on 29 June, 1966, President Illia was overthrown as a result of a military coup; the general was Juan Carlos Onganía (Zavala Ortiz 23; Frías, El Auerdo... 18). In connection with the situation, Pedro José Frías, the member of the Honorary Commission for Church and State Relations, ${ }^{13}$ who was appointed ambassador to the Holy See, was obliged to explain to the Pope what actions at the legislative level, especially those regarding the approval of treaties, were taken by the new government. Only when the fears of the Holy See were assuaged, on 10 October, 1966, the Nuncio and the Minister of Foreign Affairs, Nicanor Costa Méndez, signed a contract which (de facto) approved the Act 17.032 (Frías, Una experiencia... 91).

The doubts about the unconstitutionality of the Concordat were overcome thanks to the opinions of the constitutional doctrine, which, in principle, considered such a solution to be consistent with the highest law of the Republic (Ramella 202; Vanossi 267-68). Despite the successive coups and military upheavals and frequent changes in the post of President, no government, civilian or military of Argentina, never tried to ignore the provisions of this agreement.

\section{Concordat provisions analysis}

The text of the Concordat begins with the confirmation of the rules that were followed by both parties in concluding it. In the preamble to the document, the Holy See appealed to the principles of the Second Vatican Council, and Argentina declared activities inspired by the principle of freedom, enshrined in the Constitution (Bidart Campos, Tratado... 56, A. G. Padilla 10), in order to update the Church's legal situation. ${ }^{14}$ Attention is also drawn to the use of the word actualizar, which was chosen very carefully in the context of changes introduced in the state-church relations.

In the first article of the Concordat, there are rules of interpretation to be applied when analysing the normative text of the contract. According to them, the state "recognises and guarantees to the Church the free and full exercise of its spiritual power", as well as "free and public exercise of its cult" and "its jurisdiction in the sphere of its competence to achieve its specific goals." 15 It should

13 Created between 1958 and 1962 by the Undersecretary of Culture Ángel Centeno, together with lawyers Juan Casiello and Ramiro de Lafuente.

"Ratifcose la convención con la Santa Sede," La Nación, Buenos Aires, 29/1/1967.

15

Art. I: „El Estado Argentino reconoce y garantiza a la Iglesia Católica Apostólica Romana el libre y pleno ejercicio de su poder espiritual, el libre y público ejercicio de su culto, así como de su jurisdicción en el ámbito de su competencia para la realización de sus fines específicos." 
be surmised that the agreement assumed the inability to limit the autonomy of the Church, both in relation to communication with Rome and its internal selforganisation, which was confirmed directly of the Art. IV Concordat (Frías, El Auerdo... 359). Such an understanding of the principles of cooperation should be considered in the context of Art. 2 of the Constitution, referring to the state's duty to uphold Catholic worship. This provision was also a justification for the activities undertaken as part of the patronage. The Concordat separated, in a material sense, the constitutional norm contained in Art. 2 from the patronage right. Thus, it removed one of the main reasons for leaving the institution's regulation in the text of the Constitution. Thanks to this, it gave grounds for amending the Constitution in this area.

The free and full exercise of ecclesiastical jurisdiction, which the state recognised and guaranteed, was discussed by the Supreme Court in two judgments. The first of these concerned the confiscation of a building, an estate intended for the seat of a diocese and housing for clergy, which the church authority considered to be a "temple or sacred object," in accordance with Art. 2345 of the Civil Code. This norm assumed for them a separate from the state regime, which corresponded to the norms of canon law and regulations resulting from the patronage. ${ }^{16}$ For the Court, art. I Concordat, which referred to the Church's law in this regard, meant only them from the regulations created by the secular authority. Therefore, the property could be sold only in accordance with the canons of ecclesiastical law, and any interference with them should be considered or recognised in the Republic only according to the canonical order, especially Art. 1254 of the Code of canon law. ${ }^{17}$ The interpretation of the above-mentioned ruling is obvious because in its justification the application of the canon law norms in the Argentine legal system was clearly indicated. Taking into account the subjective scope encompassing this form of reception of law, it should be pointed out that the concept of Church property has been included in it in a broader sense than before. It went beyond objects intended solely for religious worship (von Ustinov 493-96). The court broadly applied the conditions for excluding them from enforced execution but doing so only through the interpretation of a provision that could be changed to the detriment of the Church. Therefore, the doctrine still emphasised the need to explicitly include in the Civil Code a norm qualifying Church goods as an area subject to the law of canon law (Di Nicco 57-8). In the second ruling, the court ruled on a clergyman who got married and started a family, and at the same time wanted to remain

16 Art. 2345 Codigo Civil: „Los templos y las cosas sagradas y religiosas corresponden a las respectivas iglesias o parroquias, y están sujetas a las disposiciones de los artículos 33 y 41. Esos bienes pueden ser enajenados en conformidad a las disposiciones de la Iglesia Católica respecto de ellos, y a las leyes que rigen el patronato nacional."

17 Corte Suprema de Justicia de la Nación, Lastra, Juan c/Obispado de Venado Tuerto, 22.10.1991 r., fallo 313:1324. 
an "employee" of the parish from which he had been removed. The court clearly stated that what concerns the priesthood and related obligations remains under the exclusive jurisdiction of the Church. ${ }^{18}$ In the above judgments, the court took it for granted that the state acknowledges the actions of the Church, by virtue of an international treaty, i.e. the contract of 1966 , for the sphere that is exclusively applicable to the canonical order. In other words, the state refrained from interfering in the autonomous area of the Church's activities (Serrano, Artículo 2...).

In further articles of the Concordat, there is the empowering power to create or modify the limits of church districts and to appoint archbishops and bishops of the Ordinary, prelates and coadjutors in them (Articles II and III). Only the earlier pre-notification of candidates for these positions was determined, which was to be secretly handed over to the government. Argentine citizenship was a requirement seen as a guarantee that the Holy See would not entrust the diocese to foreigners. It was also rational from the point of view of supporting Catholic worship in the form of transferring funds to bishops directly from the state budget. In practice, the nomination was always suspended until this condition was met by the designated person. The Argentine Government was also granted the right to submit "general political objections" ("objeciones de carácter político general") against the candidate within thirty days. After this period, the lack of information was interpreted as consent to the nomination (Cardoso 163-65). In practice, as far as possible, the government, through Secretaría de Culto, has expressed its opinion immediately. Usually, prior to the publication of the message on the appointment of the candidate, the State Secretariat communicates with the embassy and informs it of the date on which it will take place. The secretive nature of this procedure makes it impossible to examine the practical use of this competence (Gramajo 65-73). However, the Concordat envisages such a possibility, so if the government opposes the creation of an ecclesiastical organisational unit or the candidate's choice, the parties have committed themselves to seeking "appropriate forms of agreement" ("formas apropiadas de entendimiento") with regard to possible remarks on contentious issues. ${ }^{19}$ Although there was no formal conflict resolution procedure to which the Concordat could apply, the parties agreed on any differences that could arise in the interpretation of the provisions of this agreement.

When analysing Art. III, the previous experience of the parties should be taken into account, especially the modus vivendi. Thanks to many years of practice, they

18 Corte Suprema de Justicia de la Nación, Rybar, Antonio c. García, Rómulo y/u Obispado de Mar del Plata, 16.06.2012 r., fallo 315:1294.

19 Art. VI: "En caso de que hubiese observaciones u objeciones por parte del Gobierno Argentino conforme a los artículos segundo y tercero, las Altas Partes contratantes buscarán las formas apropiadas para llegar a un entendimiento; asimismo resolverán amistosamente las eventuales diferencias que pudiesen presentarse en la interpretación y aplicación de las cláusulas del presente Acuerdo". 
already knew how to resist conflicts over a personal background. The lack of information on the practice of presenting comments to candidates in the Concordat was a consequence, on the one hand, of recognition of the national patronage and, on the other hand, of an established practice. The Argentine government could not recognise acts incompatible with the Constitution in a legal act. A fundamental difference to the concordat arrangements was that the only acceptable objections could be those concerning the general political order, and not as before, all arguments including those personal (Mallea 20-23, 34, 40-42).

The Concordat entrusted the bishops with the installation of religious congregations in the country (Navarro Floria, Un nuevo regimen... 373). The Argentine government, at the request of the Ordinary of the place, undertook to issue a residence permit and to prepare identification documents for clergy from abroad (Docampo 433). ${ }^{20} \mathrm{~A}$ direct consequence of this clause is the Law 24.483 , binding until today, on recognising the legal personality of institutes of consecrated life and associations of apostolic life (Saguier Fonrouge 199-210).

A novelty in relation to previously concluded concordats was the failure to specify the procedure in the process for the submission of reservations. In practice, if the Holy See recognised the reservation made by Argentina, it would be accepted. If it rejected them, it could insist on the fulfilment of the previously agreed obligation without the possibility of undertaking other actions by Argentina.

In the Concordat, the right of patronage by the state party was not given up directly. The analysis of the norms of this document leaves no doubt in this matter. The regulations provide for a bilateral procedure for taking actions in the area subject to patronage. This means that the possibility of interfering in canonical matters in a unilateral manner by the state authorities was finally rejected.

\section{Consequences of introducing Concordat norms into the Argentine law system}

The controversy between the church and the state regarding the question of who should fill the capital of the archbishop of Buenos Aires in the 1920s, prompted both sides to discuss the end of patronage, even though it was only the Vatican II that finally settled the matter. While the Concordat quashed the possibility of taking action in practice under Argentine patronage, the institution remained in the text of the Constitution. This prevented the complete separation of church and state.

20 Art. V: "El Episcopado Argentino puede llamar al país a las órdenes, congregaciones religiosas masculinas y femeninas y sacerdotes seculares que estime útiles para el incremento de la asistencia espiritual y la educación cristiana del pueblo. A pedido del Ordinario del lugar, el Gobierno Argentino, siempre en armonía con las leyes pertinentes, facilitará al personal eclesiástico y religioso extranjero el permiso de residencia y la carta de ciudadanía". 
The Concordat assumed the continuation of good relations between the Argentine government and the Holy See. Although the agreement gave the Pope the power to award titles and ecclesiastical positions, the Argentine government retained the right to express its opinion in this regard.

With the entry into force of the Concordat, a complicated situation arose in the Argentine law, as the Constitution continued to contain clauses concerning the right to patronage, for example regarding the powers of the judiciary. Since 1966, these provisions have not been applied. This state of affairs lasted until the last amendment of the Constitution of 1994, when, on the occasion of a comprehensive constitutional reform, the indicated regulations were formally derogated (Ramella 202). At the same time, Concordat obtained a higher degree in the hierarchy of legal acts than the Act, pursuant to Art. 75 paragraph 22 of the Constitution.

The first reform resulting from the adoption of the Concordat concerned Art. 228 of the Criminal Code. This provision imposes a prison sentence of one to three years on anyone who has performed or ordered the making of canonical documents without obtaining consent for their effectiveness in the domestic legal order and from one to six years when the Congress has expressly refused such consent. In the amendment to this provision, the reference to canon law was removed, and the wording referring to the internal law of third countries was introduced.

In two cases decided by the Supreme Court in the early 1990s, it was stated that one of the consequences of accepting the Concordat was the recognition of the autonomy of the Church in canonical matters. Thus, they were excluded from the jurisdiction of the state, whose task was always to exclude itself from interfering with the internal law of the Church. The scope of the subject covered the inviolability of church property and the lack of the possibility to verify matters of a purely spiritual nature, i.e. mainly referring to the freedom of conscience.

Despite the fact that they did not comply with the Constitution from before its 1994 reform, the norms of the Concordat could not be removed; neither could the state authorities be obliged to reform them. As an international obligation, their legal force was limited to defining obligations for parties that must be observed and, if necessary, implemented by appropriate means. Thus, the obligation of legal and moral coherence arose with what was agreed to adapt the norms to the system of national law (Bidart Campos, Manual... 544-46).

In 1993, pursuant to Act No. 24.309, the reformed Constitution created the possibility of adapting the text to the Concordat, eliminating all clauses directly or indirectly limiting the concordat regime from the Constitution. In March 1994, before the meeting of the Convention, the Conference of the Episcopate of Argentina issued the document "La Iglesia Católica y la reforma constitucional," which provided for the replacement of articles on the Concordat with phrases similar to those included in the Constitution of the province of Cordoba, which was guaranteed free and public worship to the Catholic, apostolic and Roman Catholic Church. This was 
justified by the tradition and culture of the region's inhabitants. Institutional relations were based on the principle of autonomy and cooperation. The restrictions concerned only morality, good manners and public order. ${ }^{21}$ This Constitution also guaranteed the freedom of conscience and religion as an inviolable law, and on the issue of religious practices it made for restrictions resulting from morality and public order. In addition, no one would be forced to declare their religion. ${ }^{22}$

The reform project prepared by the Comisión de Integración y Tratados Internacionales de la Convención maintained, among the attributes of the Congress, the approval or rejection of concordats with the Holy See. ${ }^{23}$ According to the report to the project, it was mandatory to abolish the patronage, which had practically ceased since 1966. Since the conclusion of the international agreement, the government no longer had competence in matters of patronage or acceptance of religious orders, because the Church has the right to free and make full use of individual spiritual power, worship and jurisdiction. According to the opinion of the Comisión de Redacción ${ }^{24}$ the Congress has the right to approve or reject treaties concluded with other states and international organisations, as well as concordats with the Holy See. Treaties and concordats take precedence over national laws in art 67, inc. 22. This subject was not discussed at the plenary session. The attention of the convention focused on international treaties.

As to the requirement that the President should be a member of the Catholic community, at the meeting of 28 July 1994 and also on 2 August, it was implicitly accepted that any manifestation of the right of patronage should be excluded from the text of the Constitution.

\section{Conclusion}

Despite the Concordat norms repealing the rights resulting from the patronage, the Argentine government and the Catholic Church remained connected. The intra-ecclesial conflicts arising between bishops and priests erupted due

21 "La Nación Argentina, de acuerdo a su tradición cultural, reconoce y garantiza a la Iglesia Católica Apostólica Romana el libre y público ejercicio de su culto. Las relaciones de ésta y el Estado Federal se basan en los principios de autonomía y de cooperación. Igualmente garantiza a los demás cultos su libre y público ejercicio, sin más limitaciones que las que prescriben la moral, las buenas costumbres y el orden público" (cfr. Art. VI).

22 "Son inviolables la libertad de conciencia y la libertad religiosa. Su ejercicio queda sujeto a las prescripciones de la sana moral y el orden público. Nadie puede ser obligado a declarar la religión que profesa" (Art. V).

23 Juana Pablo Cafero, Enrique De Vedia, Zelmira M. Regazzoli, Hugo B. Rodrígueza Sañudo, Jorge D. Amena, Esteban M. Llamosas, Julio C. Aráoz,

24 Carlos Corach, Antonio M. Hernández, Rafael A. González, Juan C. Hitters, César Arias, Juan C. Maqueda, Horacio D. Rosatti, Alberto M. García Lema, René S. Orsi. 
to misunderstandings regarding their attitudes towards state power. ${ }^{25}$ The Church's own problems took place in the context of the political and economic turmoil in Argentina.

The issue of signing the Concordat was present in Argentine history from the beginning of independence. Argentine Governments did not deny the fact that the regulation of relations with the Catholic Church should become the subject of a bilateral agreement. As soon as it was possible to establish contacts with Rome, interrupted by breaking relations with the Crown, necessary steps were taken in this direction (Duran 138-140). This goal dominated the first years of political activity of the new state. During the course of the modus vivendi, the activities aimed at signing the contract were discontinued in mutual relations with the Church, but the mid-twentieth century was marked by a return to the previous plans, finally completed by signing the Concordat in 1966.

Finally, it was assumed that the relations between the Church and the state in Argentina had to be determined at the state level. The process of establishing and adopting an international agreement with the Holy See began shortly after the election of Pope John XXIII. At the end of 1958, President Arturo Frondizi asked the Holy See to take action to sign a concordat with Argentina. While the administration of Pedro Aramburu restored the Church's rights lost during Perón, it also proved that the Argentine Governments, especially those resulting from a military coup, exercised the right of patronage in accordance with their interests. ${ }^{26}$ Four ruling teams (Arturo Frondizi, José María Guido, Arturo Umberto Illíi and Juan Carlos Onganía) of different origins and political ideologies were needed to complete the concordat negotiations. The signing of the contract in 1966 gave the appropriate ecclesiastical authority the right to nominate and appoint bishops in Argentina just a decade before another military coup.

The contract was approved by the actual executive on 23 November, but not by Congress which then did not work. In connection with this, there were allegations regarding the validity of this international agreement, referring to the jurisdiction of the judiciary to decide on its compliance with national law, as well as to the process of ratification and the possibility of invoking the invalidity of the treaty by the party (Vanossi 266-69). The gradual implementation of concordat norms, in particular the constitutional reform of 1994, removed all grounds for raising hypothetical objections. Both the subject scope, which does not exhaust the list of matters that may be subject to bilateral regulations between the state

25 This conflict affected parish priests and bishops in particular, as the former demanded progress and reform of the law, while the latter did not agree to any radical changes.

26 It was clear from their actions that governments dominated by the military did not hesitate to use the Argentinean Church for their own purposes. Under Aramburu, the Supreme Court refused to approve the appointment of two bishops, which was a political decision and was not justified by the legislation in force at the time. 
and the Church, and the plural "concordats" used in the constitutional text, allow the assumption that the state's ability to conclude agreements with the Holy See has not been exhausted by adopting a document in 1966. The axis of the Argentinian state's relations with the Catholic Church has been definitely and finally shifted from the patronage right to the concordat system in force today.

The historical process of shaping relations between the Church and the state in Argentina has had a significant impact on contemporary relations in this area. It forms the basis for assessing the state's relations with the Catholic Church over many years, starting from colonial times. Against this background, it is important to consider the current norms of ecclesiastical law, which must take into account the presence of non-Catholic religious communities, the number and percentage of which increase with each year. A critical analysis of the issue of patronage in the Argentine Concordat is important in order to assess the current norms of ecclesiastical law, especially in the context of institutional relations not only with the Catholic Church, but also with other religious entities.

\section{Works Cited}

Acuerdo entre la Santa Sede y la República Argentina. Web. 12 Nov. 2018 http:// www.vatican.va/roman_curia/secretariat_state/archivio/documents/ rc_seg-st_19661010_santa-sede-rep-argent_sp.html

"Antecedentes y resoluciones sobre el Culto." Recopilación encomendada por el Exmo. Señor Ministro de Relaciones Exteriores y Culto a la Subsecretaría de Justicia antes a cargo del despacho del Culto, Buenos Aires, 1899.

Bermúdez, H. "La libertad religiosa en la Constitución Nacional." La libertad religiosa en el derecho argentino. Eds. R. Bosca, J.G. Navarro Floria, Buenos Aires: Konrard Adenauer Stiftung, 2007.

Bidart Campos, G. J. Manual de la Constitución reformada. Buenos Aires: Ediar, 1998. Bidart Campos, G. J. Tratado elemental de Derecho Constitucional, t. 1: El derecho constitucional de la libertad. Buenos Aires: Ediar, 1986.

Bruno, C. Base para un concordato entre la Santa Sede y la Argentina. Buenos Aires: Poblet, 1947.

Bruno, C. Historia de la Iglesia. Vol. IX, Buenos Aires: Don Bosco, 1974.

Cardoso, J. C. Actualidad de las relaciones entre las confesiones religiosas y el Estado argentino. Foro Internacional Sobre Libertad Religiosa. Memoria, México: Secretaría de Gobernación, 2003.

Casaroli, A. "Discurso del Emmo. Cardenal en la conmemoración de los treinta años del acuerdo." Anuario Argentino de Derecho Canónico 3 (1996): 360-369.

Casiello, J. Iglesia y Estado en la Argentina. Regimen de sus relaciones. Buenos Aires: Poblet, 1948. 
Centeno, Á. M. Cuatro años de una política religiosa. Buenos Aires: Desarrollo, 1964. Corte Suprema de Justicia de la Nación, Lastra, Juan c/Obispado de Venado Tuerto, 22.10.1991, fallo 313:1324.

Corte Suprema de Justicia de la Nación, Rybar, Antonio c. García, Rómulo y/u Obispado de Mar del Plata, 16.06.2012, fallo 315:1294.

Decree-Law No 7623/1957.

"Decretum de erectione Vicariatus Castrensis." Acta Apostolicae Sedis 49 (1957): 866-868.

de Lafuente, R. "El acuerdo entre la Santa Sede y la República Argentina”, Revista Española de Derecho Canónico XXIII (1967): 111-125.

de Lafuente, R. "La situación concordataria argentina", La institución concordataria en la actualidad (trabajos de la XIII semana de Derecho Canónico). Consejo Superior de Investigaciones Científcas, Salamanca: Instituto "San Raimundo de Peñafort", 1971.

de Lafuente, R. Patronato y concordato en la Argentina. Buenos Aires: Talleres Gráficos Pamaret, 1957.

Di Nicco, J. A. "Comentario de un caso judicial inédito: diócesis, parroquia, municipio y la observancia del Derecho Canónico." Prudentia Iuris 77 (2014): 51-60.

Docampo, R. "Derechos migratorios de los religiosos." La libertad religiosa en el derecho argentino. Eds. R. Bosca, J. G. Navarro Floria, Buenos Aires: Konrard Adenauer Stiftung, 2007.

Duran, J. G. "Las relaciones diplomáticas entre el gobierno argentino y la Santa Sede. Notas históricas sobre un posible concordato (1853-1892)”, Anuario argentino de derecho canónico 14 (2007): 131-156.

Estrada, J. M. La Iglesia y el Estado. Buenos Aires: W.M.Jackson, 1944.

Frías, P. J. "El Acuerdo entre la Santa Sede y la República Argentina". Anales de la Academia Nacional de Derecho y Ciencias Sociales de Córdoba XXV (1986): 223-262.

Frías, P. J. "El Acuerdo entre la Santa Sede y la República Argentina". Anuario Argentino de Derecho Canónico III (1996): 357-360.

Frías, P. J. Una experiencia diplomática en Bélgica, la Santa Sede y la Mediación Papal. Cordóba: El Copista, 1999.

Furlong, G., Baliña, L. M., Ferrer, G., Allende, J. A., Etapas de catolicismo argentino. Buenos Aires: Difusión, 1952.

García De Loydi, L. "El vicariato castrense: síntesis histórica." Archivum IV 2 (1960): 688-697.

García De Loydi, L. La Iglesia frente al peronismo. Bosquejo histórico. Buenos Aires: CIC, 1956.

González Calderón, J. A. Derecho constitucional, vol. 2. Buenos Aires: Lajouane, 1951. 
Gramajo, J. M. "Los acuerdos celebrados entre la República Argentina y la Santa Sede." La libertad religiosa en el derecho argentino. Eds. R. Bosca, J.G. Navarro Floria, Buenos Aires: Konrard Adenauer Stiftung, 2007.

Hanna, M. "Obispado castrense para las FF.AA. y de seguridad en la República Argentina." La libertad religiosa en el derecho argentino. Eds. R. Bosca, J.G. Navarro Floria, Buenos Aires: Konrard Adenauer Stiftung, 2007.

Kaufmann, J. L. La presentación de obispos en el patronato regio y su aplicación en la legislación argentina. Buenos Aires: Dunken, 1996.

Legón, F. J. Doctrina y ejercicio del patronato nacional. Buenos Aires: J. Lajouane\&Cía, 1920.

Levaggi, A. "Historia del concordato en la República Argentina. En torno al Acuerdo con la Santa Sede del 10 de octubre de 1966." Épocas. Revista de Historia 16 (2017): $47-136$.

Levaggi, A. "Intento de la provincia de Corrientes de celebrar «una especie de concordato» con el obispo Mariano Medrano." Revista de Historia del Derecho 26 (1998): 211-232.

Mallea, E. C. "El Concordato de 1966 y la práctica anterior." Prudentia Iuris XVIIXVIII (1986): 13-44.

Navarro Floria, J. G. "La singular situación de los capellanes militares." Trabajo y Seguridad Social 35 (2008): 252-278.

Navarro Floria, J. G. "Precisiones jurídicas en torno al obispado castrense de la Argentina", Buenos Aires, 2005, Web. 12 Nov. 2018 http://www.calir.org.ar/docs/ pubre105001.pdf

Navarro Floria, J. G. "Un nuevo régimen legal para los religiosos." Criterio 27 July (1995).

Oviedo Cavada, C. "El Concordato de San Juan de Cuyo (Argentina) 1833-1834." Estudios 18 (1962): 243-255.

Padilla, A. G. Lecciones sobre la Constitución. Buenos Aires: Perrot, 1965.

Padilla, N. A treinta años del acuerdo con la Santa Sede. disertación en la Universidad de Norte Santo Tomás de Aquino, San Miguel de Tucumán, 13 de mayo de 1996.

Padilla, N., Navarro Floria, J. G. Asistencia religiosa a las Fuerzas Armadas - En el 40 Aniversario del Acuerdo entre la Nación Argentina y la Santa Sede sobre jurisdicción castrense. Buenos Aires: Ministerio de Relaciones Exteriores, Comercio Internacional y Culto, 1997.

Ramella, P. Derecho Constitucional, Buenos Aires: Depalma, 1982.

Río, M. "Concordatos con la Santa Sede. Recuerdos de una misión diplomática." Anales. Biblioteca de la Academia Nacional de Derecho y Ciencias Sociales de Buenos Aires 13 (1973): 59-74.

Saguier Fonrouge, L. "Práctica administrativa del Derecho Eclesiástico." La libertad religiosa en el derecho argentino. Eds. R. Bosca, J. G. Navarro Floria, Buenos Aires: Konrard Adenauer Stiftung, 2007. 
Salinas Araneda, C. "Las Relaciones Iglesia-Estado en la América Indiana: patronato, vicariato, regalismo." Estado, derecho y religión en América Latina. Eds. J. G. Navarro Floria, Buenos Aires-Madrid-Barcelona: Marcial Pons, 2009.

San Martino de Dromi, M.L. Documentos Constitucionales Argentinos. Buenos Aires: Ciudad Argentina, 1994.

Serrano, M. C. “Artículo 2." Constitución de la Nación Argentina y normas complementarias. Análisis doctrinal y jurisprudencial. Tomo 1. Artículos 1/35. Preámbulo. Declaraciones, derechos y garantías. Eds. D. A. Sabsay, P. L. Manili, Buenos Aires: Hammurabi, 2009.

Tonda, A. La Iglesia argentina incomunicada con Roma (1810-1858). Problemas, conflictos, soluciones. Santa Fe: Castellví, 1965.

Vanossi, J. Régimen constitucional de los tratados. Buenos Aires: El Coloquio, 1969.

Verdaguer, J. A. Historia eclesiástica de Cuyo. II. Milano: Scuola Tipografca Salesiana, 1932.

von Ustinov, H. A. “Expectativa satisfecha." El Derecho 145 (1991): 493-496.

Zavala Ortiz, M. A. Negociaciones para el acuerdo entre la Santa Sede y la República Argentina. Buenos Aires: Guadalupe, 1966.

Zuretti, J. C. Nueva historia eclesiástica argentina. Del Concilio de Trento al Vaticano II. Buenos Aires: Itinerarium, 1972.

Marta Zuzanna Osuchowska - Ph.D., Assistant Professor at the Faculty of Law and Administration, UKSW. She is a graduate of the Faculty of Law at Administration at UKSW and the Faculty of Canon Law, UKSW. Postgraduate in Latin American Studies - Center for Latin American Studies (CESLA) University of Warsaw. Ordinary member of the Polish Society for Ecclesiastical State Law and extraordinary member of the Consorcio Latinoamericano de Libertad Religiosa. Her research centres on concordats, legal regime of religious associations, legal personality of religious communities (especially in the Latin American region). 